\title{
Impact of Different Shades of Plastic Mulch and Plant Geometry on Yield and Economics on Tender Stem Broccoli in Punjab, India
}

\author{
Ramendra Singh * and Jeewesh Kumar \\ Agri. Centre of Excellence Field Fresh Foods Pvt. Ltd. Ludhiana, Punjab, India \\ *Corresponding author
}

\begin{tabular}{|c|c|}
\hline & A B S T R A C T \\
\hline & \multirow{6}{*}{ 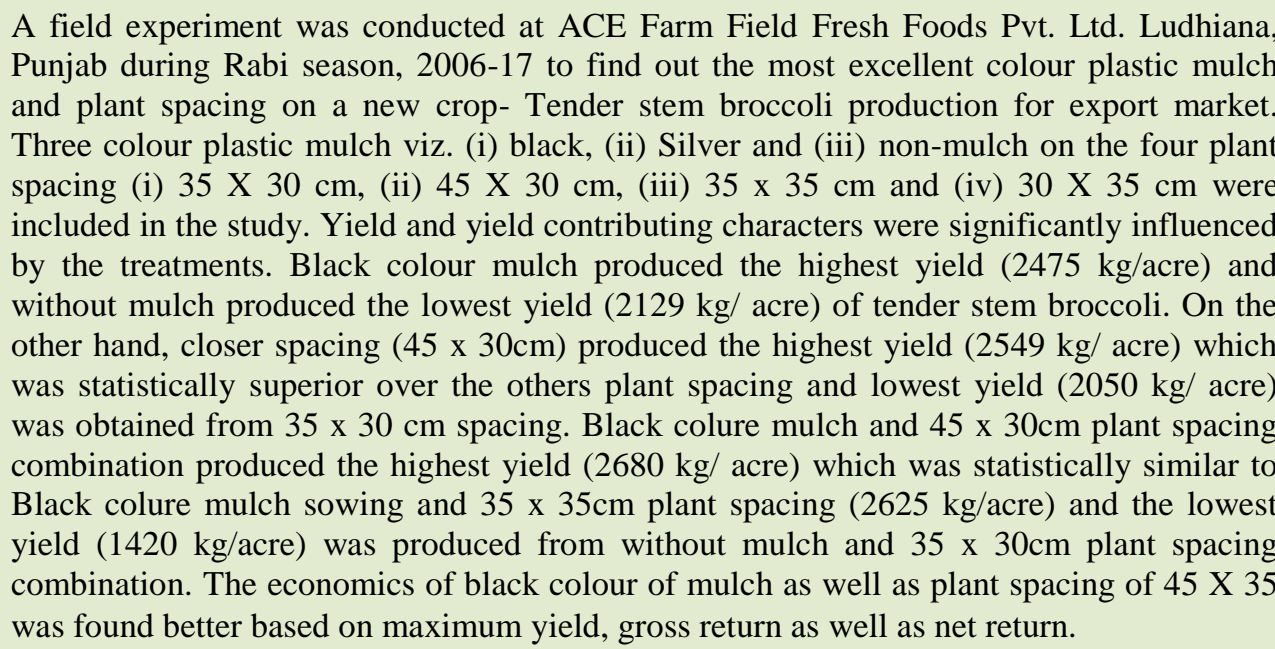 } \\
\hline Keywords & \\
\hline $\begin{array}{l}\text { Colour plastic } \\
\text { mulch, Plant } \\
\text { spacing, Yield, } \\
\text { Tender stem } \\
\text { broccoli, Return. }\end{array}$ & \\
\hline Article Info & \\
\hline $\begin{array}{l}\text { Accepted: } \\
30 \text { September } 2 \\
\text { Available Onlin } \\
10 \text { November } 2\end{array}$ & \\
\hline & \\
\hline
\end{tabular}

\section{Introduction}

Tender Stem or tender stem broccoli is a green vegetable similar to tender stem broccoli but with smaller floret and longer, thin stalks. Often misidentified as young tender stem broccoli, it is a hybrid of tender stem broccoli and Chinese Kale which was first developed in 1993 by Sakata Seed Company in Yokohama, Japan, Sakata. Presently due to its small florets and subtle sweet flavor it is very popular in European market.

Broccoli (Brassica oleracea L.) is one of the most prominent vegetables grown all over the world. This vegetable, closely resembling cauliflower but usually green in colour, introduced in India many years after cabbage and cauliflower, has gained popularity in short span of time. Besides being used as vegetable, the tender fresh leaves are served as salad and are extensively used in the preparation of pickles. It has very high nutritional value due to its high content of protein, carbohydrates, fibers, calcium, iron, carotene, thiamine, riboflavin and ascorbic acid. It also helps in digestion and assimilation of food in human body. With the increased popularity of the vegetable in recent years and its high nutritional value, it is a 
good candidate for expanded production in India. High level of cancer fighting chemical "sulforaphane" in it mobilizes the human body to combat cancer naturally and increase resistance to cancer.

The main mulches in vegetable crops cultivation is to protect the soil surface from the influence of unfavorable factors and to improve the growing conditions for the crop plants (Olfati et al., 2008). They reduce soil wind and water erosion, conserve soil moisture and help maintain stable soil temperature (Kar and Kumar 2007). Mulch increases soil porosity and suppresses weed growth (Uwah and Iwo 2011). Tan et al., (2000) claim that plant's growth conditions are the main determinant of the quality of their yield. The application of plastic covers can have a significant influence on the vegetables yield. Covers are used to modify plants environment in order to optimize plants growth, increase yields and improve their quality. The profitable conditions under the covers resulted in higher yield for early potato (Hamouz et al., 2007).

According to Gordon et al., (2010) an increase in soil temperature and moisture under covers will not always cause an increase in the yield of plants. Spacing of plant affects both total yield and the size of Tender stem broccoli head. According to recent field tests, wider spacing contributes towards larger and heavier heads while, yield per hectare can be increased by close spacing. Hence, it is necessary to optimize proper plant spacing for obtaining higher yield with better quality. The study aimed to determine which colour mulch and plant spacing perform better on the yield and quality of Tender stem broccoli cultivated for early harvest.

\section{Materials and Methods}

A field experiment was conducted to study the influence of different colour plastic mulch
(Black mulch, silver mulch and non-mulch) and plant spacing $(35 \times 30 \mathrm{~cm}, 45 \times 30 \mathrm{~cm}$, $35 \times 35 \mathrm{~cm}$ and $30 \times 35 \mathrm{~cm}$ ) on growth and yield of Tender stem broccoli. It is a new crop for India. Plant height, yield, fruit number and dry weight of plant increased with increasing $\mathrm{K}$ levels and mulching. The advantages of mulching in vegetable crop production have been well documented. Various mulching materials are utilized and these include weed or grass clippings, paddy straw, bark, sawdust and plastic. Mulches can effectively minimize water vapour loss, soil erosion, weed problems and nutrient loss. The most common response to mulch is an increase in total yield. The reflective plastic mulches can reduce the incidence of aphid-borne viruses and exclude some species of pest. Little information is available concerning the use of mulches in India although its application has been gradually expanding. Most local vegetable farmers use plastic and plant residue mulching. The current recommended rates of fertilizer for chilli are normally for planting system without mulching. However, mulches are already known to be effective in reducing nutrient losses through leaching. This experiment was conducted to determine the effect of various colour plastic mulch and plant spacing materials on the growth and yield of Tender stem broccoli.

\section{Layouts and treatments}

An experiment was conducted at Agri centre of excellence, Ladhowal to observe the impact of plant spacing under black plastic, silver mulch and non-mulch condition on vegetative traits and yield of Tender stem broccoli. Both under mulch and un-mulch, four different plants to plant spacing were taken as treatment. Plants to plant spacing were as follows: i. $35 \times 30 \mathrm{~cm}$, ii. $45 \times 30$, iii. $35 \times 35 \mathrm{~cm}$, iv. $30 \times 35 \mathrm{~cm}$. The experimental design was a split plot with three replications. Main plots were different colour plastic mulch viz., Black mulch, silver 
mulch and non-mulch, while subplots were treated with plant spacing $35 \times 30 \mathrm{~cm}, 45 \mathrm{X}$ $30 \mathrm{~cm}, 35 \times 35 \mathrm{~cm}$ and $30 \times 35 \mathrm{~cm}$. Firstly, nursery was raised in plug tray in the month of 6 September 2016 and seedlings were transplanted in the 19 October 2016. Transplanting was done on $90 \mathrm{~cm}$ raised beds both in mulch and un-mulch conditions.

\section{Results and Discussion}

No significant interaction of mulching materials was observed with plant spacing in any of the measured parameters; thus, only main effect data are reported. Height $(\mathrm{cm})$, No. of leaves, Days taken to first harvest, No. of curds harvested/plant, No. of curds/acre, Avg. wt. (g) of the curd and Yield/acre (kg) Recovery (\%) were significantly higher than those without mulches (Table 1).

\section{Effect of mulch}

It has been observed in the experiment that height of the plant was significantly different in between mulch and un-mulch planting. In black plastic mulch condition, highest plant height was observed as $78.6 \mathrm{~cm}$, where as in silver mulch condition $(73.7 \mathrm{~cm})$ and lowest plant height was recorded highest as only 61.5 $\mathrm{cm}$ in non-mulch condition.

In case of number of leaves also black mulching condition showed maximum number of 47 leaves /plant was recorded followed by silver colour (45 leaves/plant) and non-mulch (42 leaves /plant). In case of days taken to first harvest no significant difference recorded with 65 day first harvest taken in all colour of mulch and non-mulch.

The black mulch showed superiority with maximum number of curd/plant in comparison to silver colour mulch and nonmulch condition. In black colour mulch maximum14.0 curd/plant was recorded after that silver colour (13.8 curd /plant) and nonmulch (13.5 curd /plant). Number of curds per acre was also varied significantly in comparison both mulching and un-mulching plots. Highest number of curds harvested in black colour mulch (30175 numbers) and followed by silver colour mulch (29576 numbers).

This figure was significantly higher than the un-mulching plot where in non-mulch condition number of curds harvested was recorded as 29123 numbers of curds. If comparison is done among all spacing of mulching and un-mulching plot, it has been observed that number of curds were higher in maximum plant spacing in mulching plot than the un-mulching plot. In case of average weight per curd, also black colour mulch was found most effective with highest weight $7.6 \mathrm{~g}$ in comparison to other mulch and nom mulch and lowest curd weight $6.8 \mathrm{~g}$ was noticed in non-mulch plots.

Maximum Tender stem broccoliyield 2475 $\mathrm{kg} /$ acre was recorded by black colour plastic mulch along with highest $55.1 \%$ recovery of produce followed by silver colour mulch $2310 \mathrm{~kg}$ yield/acre with $53.6 \%$ recovery and minimum yield $21.29 \mathrm{~kg} /$ acre was noticed in non-mulch plots with $49.6 \%$ recovery. Kosterna (2014) recorded the application of polypropylene fibre contributed to a significant increase in the marketable yield of Tender stem broccoli on average by $5.25 \mathrm{t} / \mathrm{ha}$, weight of head by $0.10 \mathrm{~kg}$ and length of arc by $1.44 \mathrm{~cm}$. In the study by Awodoyin et al., (2007) mulching increased growth of plants and yield of tomato fruit. Sinkeviciene et al., (2009) reported that yield of vegetables depended on the kind of mulch application to soil mulching.

At conducted research the content of dry matter in Tender stem broccoli ranged from $7.69 \%$ to $10.75 \%$ (Grabowska et al., 2009). 
Table.1 Effect of different colour plastic mulch and plant spacing on Tender stem broccoli

\begin{tabular}{|c|c|c|c|c|c|c|c|c|c|c|}
\hline Treatment & $\begin{array}{c}\text { Height } \\
\text { (cm) }\end{array}$ & $\begin{array}{l}\text { No. of } \\
\text { leaves }\end{array}$ & $\begin{array}{c}\text { Days taken } \\
\text { to first } \\
\text { harvest }\end{array}$ & $\begin{array}{c}\text { No. of curds } \\
\text { harvested/ } \\
\text { plant }\end{array}$ & $\begin{array}{c}\text { No. of } \\
\text { curds/acre }\end{array}$ & $\begin{array}{l}\text { Avg. wt. (g) } \\
\text { of the curd }\end{array}$ & $\begin{array}{l}\text { Yield/acre } \\
\text { (kg) }\end{array}$ & CoC (Rs.) & $\begin{array}{c}\text { Gross } \\
\text { returns } \\
\text { (Rs.) }\end{array}$ & $\begin{array}{c}\text { Net Return } \\
\text { (Rs.) }\end{array}$ \\
\hline \multicolumn{11}{|l|}{ Mulch } \\
\hline None & 69.5 & 42 & 65 & 13.5 & 29123 & 6.8 & 4129 & 74483 & 123870 & 49387 \\
\hline Silver plastic & 73.7 & 45 & 65 & 13.8 & 29576 & 7.4 & 4310 & 74745 & 129300 & 54555 \\
\hline Black plastic & 76.2 & 47 & 65 & 14.0 & 30175 & 7.6 & 4475 & 76580 & 134250 & 57670 \\
\hline S. Ed. $( \pm)$ & 1.76 & 0.62 & 0.09 & 0.10 & 209 & 0.71 & 64 & - & - & - \\
\hline C. D. $(0.05)$ & 3.36 & 1.28 & NS & 0.25 & 443 & 1.45 & 135 & - & - & - \\
\hline \multicolumn{11}{|l|}{ Plant spacing } \\
\hline $35 \times 30 \mathrm{~cm}$ & 70.0 & 41 & 65 & 13.1 & 27190 & 7.0 & 4050 & 73558 & 121500 & 47942 \\
\hline $45 \times 30 \mathrm{~cm}$ & 78.6 & 48 & 65 & 14.8 & 30670 & 7.9 & 4549 & 71554 & 136470 & 64916 \\
\hline $35 \times 35 \mathrm{~cm}$ & 75.0 & 46 & 65 & 14.0 & 29165 & 7.5 & 4254 & 72125 & 127620 & 55495 \\
\hline $30 \times 35 \mathrm{~cm}$ & 74.1 & 43 & 65 & 13.5 & 28853 & 7.2 & 4187 & 74320 & 125610 & 51290 \\
\hline S. Ed. $( \pm)$ & 1.40 & 0.83 & 0.07 & 0.37 & 196 & 0.50 & 76 & - & - & - \\
\hline C. D. $(0.05)$ & 2.87 & 1.56 & NS & 0.78 & 395 & 0.98 & 148 & - & - & - \\
\hline
\end{tabular}

*Mean separation in columns by Duncan's multiple range test, $5 \%$ level. NS Not significant

Fig.1 Combined effect of colour plastic mulch and plant spacing on yield of Tender stem broccoli

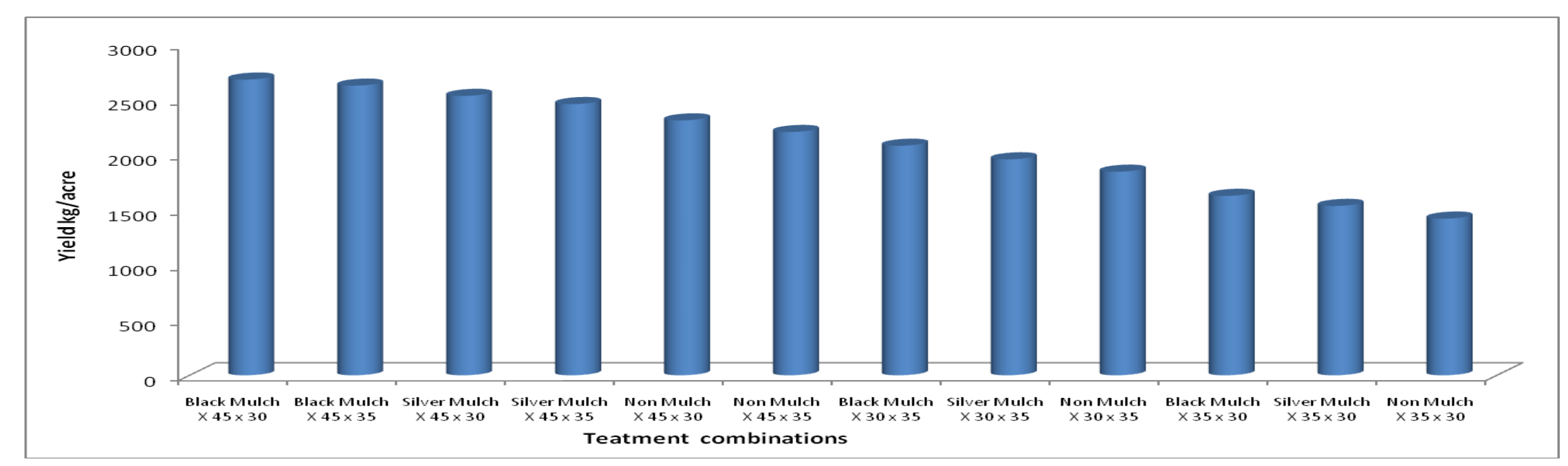




\section{Effect of plant spacing}

The more plant spacing showed most effective in comparison to less plant spacing. The highest height of the plant was achieved as $78.6 \mathrm{~cm}$ in $45 \mathrm{X} 30 \mathrm{~cm}$ spacing followed by 35 X $35(75.0 \mathrm{~cm}), 30$ X $35 \mathrm{~cm}(74.1 \mathrm{~cm})$ and lowest $70.0 \mathrm{~cm}$ plant height was noticed in plant spacing $35 \times 30 \mathrm{~cm}$. In case of number of leaves also $45 \times 35 \mathrm{~cm}$ plant spacing was found most effective with maximum number of leaves 48/plant and followed by $46 \mathrm{~cm}, 43 \mathrm{~cm}$ and $41 \mathrm{~cm}$ in respective plant spacing $45 \times 30 \mathrm{~cm}, 35 \times 35$ $\mathrm{cm}$ and $30 \times 35 \mathrm{~cm}$ ). In case of days taken to first harvest no significant difference recorded with 65 day first harvest taken in all treatments. In all the spacing of mulching and un-mulching plot, it has been noted that harvesting started on the similar day i.e. number of days taken for first harvest was same in case of all spacing in both and unmulch conditions. Number of curds harvested/plant was ranged in 13 to 15 numbers in all spacing of mulch and unmulch conditions. The more plant spacing showed superiority with maximum number of curd/plant in comparison to less plant spacing. In $45 \times 35$ plant spacing, maximum 14.8 curd/plant was recorded after that 14.0 curd/plant, 13.5 curd /plant and 13.1 curd /plant were recorded by in respective plant spacing $45 \times 30 \mathrm{~cm}, 35 \times 35 \mathrm{~cm}$ and $30 \times 35$ $\mathrm{cm} 70 \mathrm{~cm}$. It clearly indicated that mulching technique and more plant spacing have showed significant impact on vegetative growth of the TSB crop as seen in the experiment. Number of curds per acre was also varied significantly as per plant spacing plots. Highest number of curds harvested in plant spacing 45 X $30 \mathrm{~cm}$ (30670 numbers) and followed by plant spacing $35 \times 35 \mathrm{~cm}$ (29165 numbers), 3o X $35 \mathrm{~cm}$ and (28853 numbers of curd). This figure was significantly higher than the other plant spacing condition number of curds harvested was recorded as 27190 numbers of curds. If comparison is done among all spacing of mulching and un-mulching plot, it has been observed that number of curds were higher in maximum plant spacing in mulching plot than the un-mulching plot. In case of average weight per curd, also plant spacing $45 \times 35$ $\mathrm{cm}$ was found most effective with highest weight $7.9 \mathrm{~g}$ in comparison to other plant spacing and lowest curd weight $7.0 \mathrm{~g}$ was noticed plant spacing $35 \times 30 \mathrm{~cm}$. Maximum Tender stem broccoli yield $2549 \mathrm{~kg} /$ acre was recorded by plant spacing $45 \times 35$ along with highest $56.8 \%$ recovery of produce followed by $35 \mathrm{X} 35 \mathrm{~cm} 2254 \mathrm{~kg}$ yield/acre with 54.2 $\%$ recovery and minimum yield $2050 \mathrm{~kg} / \mathrm{acre}$ was noticed in plant spacing $35 \times 30$ with $50.0 \%$ recovery. If comparison is done among all spacing of mulching and unmulching plot, it has been observed that number of curds were higher in all spacing in mulching plot than the un-mulching plot. However, the main head yield of Tender stem broccoli was significantly different from one treatment to another. $60 \mathrm{~cm} \times 40 \mathrm{~cm}$ plant spacing produced the highest main head yield and $60 \mathrm{~cm} \times 60 \mathrm{~cm}$ plant spacing produced the lowest main head yield. Similar results had got by Pornsuriya et al., (1997). Main head yield and total yield of Tender stem broccoli followed the same trend in response to plant spacing. Increasing the plant number per plot decreased the head size but increased the yield (Nassar et al., 1972). Solunke et al., (2011) reported that the Tender stem broccoli transplanted on the 1st date of planting i.e. 15th September reported significantly maximum yield (122.14 q ha-1) over the other dates of planting, while spacing $60 \times 60 \mathrm{~cm}$ showed significantly maximum growth for height, number of leaves, stem diameter and leaf area. Interaction between dates of planting and spacing was significant in respect of curd yield/ hectare. Hossain et al., (2011) reported that 1 October sowing produced the highest yield (21.39 t/ha) and 30 
October sowing produced the lowest yield (13.6t/ha) of Tender stem broccoli. On the other hand, closer spacing $(60 \mathrm{x} 40 \mathrm{~cm})$ produced the highest yield (18.8t/ha) which was statistically similar to $60 \mathrm{x} 50 \mathrm{~cm}$ (17.6t/ha) and lowest yield (16t/ha) was obtained from $60 \times 60 \mathrm{~cm}$ spacing. Gagoi et $a l$. , (2016) reported the most of the growth parameters were not influenced by planting distances except for canopy spread, days to heading and days to flowering.

\section{Combined effect of colour plastic mulch and plant spacing on Tender stem broccoli production}

Treatment combination of colour plastic mulch and plant spacing had significant effect on yield and yield contributing characters of Tender stem broccoli production (Fig. 1). Combination of black colour plastic mulch and $45 \mathrm{~cm} \times 30 \mathrm{~cm}$ plant spacing required the minimum days to first harvest of tender stem Tender stem broccoli. Without mulch and 35 $\mathrm{cm} \times 30 \mathrm{~cm}$ plant spacing required the maximum days to first harvest. Maximum length and diameter of Tender stem broccoli head was measured from the treatment combination of black colour plastic mulch and $45 \mathrm{~cm}$ x $30 \mathrm{~cm}$ plant spacing. Black colure mulch and $45 \times 30 \mathrm{~cm}$ plant spacing combination produced the highest yield (2680 $\mathrm{kg} /$ acre) which was statistically similar to Black colure mulch sowing and $35 \times 35 \mathrm{~cm}$ plant spacing (2625 kg/acre) and the lowest yield (1420 kg/acre) was produced from without mulch and $35 \times 30 \mathrm{~cm}$ plant spacing combination.

Results of the present study revealed that black colour plastic mulch and plant spacing of $45 \mathrm{~cm} \times 30 \mathrm{~cm}$ is the preeminent for broccoli production. Maximum crop growth, curd weight and yield were found maximum in said treatment. The maximum return was also found in black plastic mulch with a plant spacing of $45 \mathrm{~cm}$ x $30 \mathrm{~cm}$ in Northern plains of India.

\section{References}

Awodoyin, R.O., Ogbeide F.I., Oluwole O. 2007. Effects of three mulch types on the growth and yield of tomato (Lycopersicon esculentum Mill.) and weed suppression in Ibadan, rainforestsavanna transition zone of Nigeria. Tropical Agricultural Research and Extension, 10: 53-60.

Gogoi, S., Milu R. Das, Bora, P., Mazumdar, N. and Das B.K. 2016. Effect of sowing dates and spacing on Tender stem broccoli (Brassica oleracea var. italica) seed production. Indian J. Agric. Res., 50 (4): 350-353

Gordon, G.G., Foshee W.G., Reed S.T., Brown J.E., Vinson E., Woods F.M. 2008. Plastic mulches and row covers on growth and production of summer squash. International Journal of Vegetable Science, 14: 322-338.

Grabowska, A., Kunicki E., Libik A. 2009. The effects of different methods of cultivation and plant spacing on the chemical composition of Tender stem broccoli heads. Folia Horticulturae, 21: 25-34.

Hamouz, K., Dvořák P., Erhartová D. 2007. Effect of polypropylene covering on the yield formation dynamics of early potatoes. Acta Fytotechnica et al., Zootechnica, 3: 57-60.

Hossain, M.F., Ara N, Uddin MR, Dey S and Islam MR. 2011. Effect of time of sowing and plant spacing on Tender stem broccoli production. Tropical Agricultural Research \& Extension 14(4): 90-92.

Kar, G., Kumar A. 2007. Effects of irrigation and straw mulch on water use and tuber yield of potato in eastern India. Agri- 
cultural Water Management, 94: 109116.

Kosterna, E., 2014. The yield and quality of Tender stem broccoli grown under flat covers with soil mulching. Plant Soil Environ. 60(5): 228-233.

Nassar, S.H., M El-Sherbni, Abdelgawad MG and Nasr MS 1972. Effect of some factors on cauli-flower seed production. Agric. Res. Rev., 50(4): 109-119.

Olfati, J.A., Peyvast Gh, Nosrati-Rad Z. 2008. Organic mulching on carrot yield and quality. International Journal of Vegetable Science, 14: 362-368.

Pornsuriya, P., Pornsuriya $\mathrm{P}$ and Teeraskulchon S 1997. Studies on Tender stem broccoli production in Chonburi Province, Thailand. Kasetsart J. Natural Sci., 32 (4): 81-85.

Sinkeviciene, A., Jodaugiene D., Pupaliene R., Urboniene M. 2009. The influence of organic mulches on soil properties and crop yield. Agronomy Research, 7: 485-491.

Solunke, B.G., Wagh, A.P., Dod, V.N. and Nagre, P.K. 2011. Effect of dates of planting and spacing on growth and yieldof Tender stem broccoli. The Asian Journal of Horticulture 6(2):294-296.

Tan, D.K.Y., Wearing A.H., Rickert K.G., Birch C.J. 2000. Tender stem broccoli yield and quality can be determined by cultivar and temperature but not photoperiod in south-east Queensland. Australian Journal of Experimental Agriculture, 39: 901-909.

Uwah, D.F., Iwo G.A. 2011. Effectiveness of organic mulch on the productivity of maize (Zea mays L.) and weed growth. The Journal of Animal and Plant Sciences, 21: 525-530.

\section{How to cite this article:}

Ramendra Singh and Jeewesh Kumar. 2017. Impact of Different Shades of Plastic Mulch and Plant Geometry on Yield and Economics on Tender Stem Broccoli in Punjab. Int.J.Curr.Microbiol.App.Sci. 6(11): 4228-4234. doi: https://doi.org/10.20546/ijcmas.2017.611.495 